\title{
Autoimmune Rheumatic Diseases: An Update on the Role of Atherogenic Electronegative LDL and Potential Therapeutic Strategies
}

\author{
Der-Yuan Chen ${ }^{1,2,3}$, Tatsuya Sawamura ${ }^{4,5}$, Richard A. F. Dixon ${ }^{6}$, José Luis Sánchez-Quesada ${ }^{7,8}$ (D) \\ and Chu-Huang Chen $5,9,10, *$ \\ 1 Translational Medicine Center, China Medical University Hospital, Taichung 404, Taiwan; \\ dychen1957@gmail.com \\ 2 Rheumatology and Immunology Center, China Medical University Hospital, Taichung 404, Taiwan \\ 3 College of Medicine, China Medical University, Taichung 404, Taiwan \\ 4 Department of Molecular Pathophysiology, Shinshu University School of Medicine, \\ Matsumoto 390-8621, Japan; sawamura@shinshu-u.ac.jp \\ 5 Department of Life Innovation, Institute for Biomedical Sciences, Shinshu University, \\ Matsumoto 390-8621, Japan \\ 6 Molecular Cardiology Research Laboratories, Texas Heart Institute, Houston, TX 77030, USA; \\ RDixon@texasheart.org \\ 7 Cardiovascular Biochemistry Group, Biomedical Research Institute IIB Sant Pau, 08041 Barcelona, Spain; \\ jsanchezq@santpau.cat \\ 8 CIBER of Diabetes and Metabolic Diseases (CIBERDEM), 08041 Barcelona, Spain \\ 9 Vascular and Medicinal Research, Texas Heart Institute, Houston, TX 77030, USA \\ 10 New York Heart Research Foundation, Mineola, NY 11501, USA \\ * Correspondence: cchen@texasheart.org; Tel.: +832-355-9026
}

Citation: Chen, D.-Y.; Sawamura, T.; Dixon, R.A.F.; Sánchez-Quesada, J.L.; Chen, C.-H. Autoimmune Rheumatic Diseases: An Update on the Role of Atherogenic Electronegative LDL and Potential Therapeutic Strategies. J. Clin. Med. 2021, 10, 1992. https:// doi.org/10.3390/jcm10091992

Academic Editor: Mitsuhiro Takeno

Received: 22 February 2021

Accepted: 2 May 2021

Published: 6 May 2021

Publisher's Note: MDPI stays neutral with regard to jurisdictional claims in published maps and institutional affiliations.

Copyright: (c) 2021 by the authors. Licensee MDPI, Basel, Switzerland. This article is an open access article distributed under the terms and conditions of the Creative Commons Attribution (CC BY) license (https:// creativecommons.org/licenses/by/ $4.0 /)$.

Abstract: Atherosclerosis has been linked with an increased risk of atherosclerotic cardiovascular disease (ASCVD). Autoimmune rheumatic diseases (AIRDs) are associated with accelerated atherosclerosis and ASCVD. However, the mechanisms underlying the high ASCVD burden in patients with AIRDs cannot be explained only by conventional risk factors despite disease-specific factors and chronic inflammation. Nevertheless, the normal levels of plasma low-density lipoprotein (LDL) cholesterol observed in most patients with AIRDs do not exclude the possibility of increased LDL atherogenicity. By using anion-exchange chromatography, human LDL can be divided into five increasingly electronegative subfractions, L1 to L5, or into electropositive and electronegative counterparts, LDL (+) and LDL (-). Electronegative L5 and LDL (-) have similar chemical compositions and can induce adverse inflammatory reactions in vascular cells. Notably, the percentage of L5 or LDL (-) in total LDL is increased in normolipidemic patients with AIRDs. Electronegative L5 and LDL (-) are not recognized by the normal LDL receptor but instead signal through the lectin-like oxidized LDL receptor 1 (LOX-1) to activate inflammasomes involving interleukin $1 \beta$ (IL-1 $\beta$ ). Here, we describe the detailed mechanisms of AIRD-related ASCVD mediated by L5 or LDL $(-)$ and discuss the potential targeting of LOX-1 or IL-1 $\beta$ signaling as new therapeutic modalities for these diseases.

Keywords: electronegative LDL; L5; atherosclerotic cardiovascular disease (ASCVD); autoimmune rheumatic diseases (AIRDs); lectin-like oxidized low-density lipoprotein receptor 1 (LOX-1); interleukin $1 \beta(\mathrm{IL}-1 \beta)$

\section{Introduction}

Atherosclerosis is a chronic inflammatory process that leads to vascular atheromatous plaque buildup, usually not developing into full-blown atherosclerotic cardiovascular disease (ASCVD) until later in life [1]. However, an exception is patients with autoimmune 
rheumatic diseases (AIRDs), who often present with accelerated ASCVD manifestations including death at a young age [2]. Rheumatoid arthritis (RA), systemic lupus erythematosus (SLE), systemic sclerosis (SSc), polymyositis (PM)/dermatomyositis (DMtis), and primary Sjögren's syndrome (pSS) [3-7] are some of the AIRDs associated with accelerated ASCVD caused by inflammatory processes that result from multiorgan immune dysregulation [8]. The high ASCVD burden in these patients can be attributed to a combination of traditional risk factors, disease-specific factors, chronic inflammation, genetic components, and the use of medications [9-18]. Genetic aberrations associated with SLE-related ASCVD include variants of the genes encoding interferon regulatory factor 8 (IRF8) [19], mannose-binding lectin [20], and signal recognition particle 54-antisense 1 (SRP54-AS1) [21]. Variants of the gene encoding apolipoprotein (apo)E have been shown to be related to ASCVD risk in patients with RA [22].

Dyslipidemia usually refers to elevated levels of total cholesterol (TC), triglycerides (TG), and low-density lipoprotein cholesterol (LDL-C) and decreased levels of high-density lipoprotein cholesterol (HDL-C) [23]. Although dyslipidemia may occur in some patients with AIRDs [24-27], plasma LDL-C levels are almost universally normal in these patients at the time of admission for ASCVD complications [28,29]. LDL is a lipoprotein class that varies in density, size, electric charge, and composition among its particles. In most experimental studies of atherogenic LDL, the LDL must first undergo ex vivo oxidation to exhibit atherogenicity, whereas native LDL, such as L1, is harmless in vitro or in vivo, even at a supranormal high concentration [30]. Notably, electronegative LDL is a naturally occurring LDL that exerts potent atherogenic effects in cells and animals without undergoing ex vivo oxidation [31].

Human plasma LDL can be divided into a dichotomy of electropositive and electronegative counterparts, namely, LDL (+) and LDL ( - ), by using anion-exchange chromatography [32]. Alternatively, LDL can also be divided into five subfractions with increasing electronegativity, called L1 to L5 [33]. L5 and LDL (-) differ from native LDL in their physicochemical and biological characteristics, including size, density, lipid and protein composition, phospholipase activity, and apo B100 conformation [34,35]. Elevations in L5 or LDL (-) percentages in total LDL have been observed in patients with familial hypercholesterolemia [36], type 1 or type 2 diabetes mellitus (DM) [37-40], coronary artery disease [41,42], uremia [43], ischemic peripheral arterial disease [44], ST-elevation myocardial infarction (STEMI) [45,46], or acute ischemic stroke [47]. Furthermore, increases in the L5 percentage (i.e., L5\%) and L5 levels are associated with the intensity of metabolic syndrome [48] and are speculated to be involved in the pathogenesis of ASCVD in patients with severe mental illness [49].

L5 and LDL (-) are not recognized by the normal LDL receptor (LDLR) because of their electronegativity; rather, they signal through lectin-like oxidized LDL receptor 1 (LOX-1) to induce a broad spectrum of inflammatory reactions in adipose tissue [50] and vascular cells [51], as well as endothelial cell (EC) dysfunction and inflammation [52] Accordingly, both L5 and LDL (-) stimulate inflammasome formation, which involves the participation and release of several cytokines, including interleukin $1 \beta$ (IL-1 $\beta$ ), IL-6, and IL-18 [51,53,54]. In monocytes, toll-like receptor 4 (TLR4) and cluster of differentiation 14 (CD14) mediate cytokine release promoted by LDL $(-)$ [54,55]. Of importance, patients with AIRDs have been documented to have elevated levels of L5 or LDL (-) in circulation [56,57]. Because AIRD-related ASCVD presents a significant threat to many young patients $[2,11,16,58,59]$, it is imperative to update the mechanistic roles of L5 and LDL (-) in the pathogenesis of AIRD-related ASCVD and the preclinical modalities that have a potential therapeutic value.

In this review, we highlight the existing evidence regarding the atherogenic roles of L5 and LDL (-) in AIRDs. Because these electronegative LDLs signal through LOX-1, the potential therapeutic implications of targeting LOX-1 are also discussed. We searched the MEDLINE database using the PubMed interface and reviewed the literature published in the English language from 1988 up to 30 November 2020. The keywords searched 
for this review included atherosclerosis, atherogenesis, vascular inflammation, ASCVD, LDL-C, oxidized LDL, electronegative LDL, LDL (-), L5 LDL, LOX-1, inflammasomes, proinflammatory cytokines, IL-1 $\beta$, AIRDs, SLE, SSc, PM/DMtis, pSS, therapeutic strategies, cytokine-targeting agents, LOX-1-targeting therapy, proprotein convertase subtilisin/kexin type 9 (PCSK9), and microRNAs. The relevant drugs included statins, corticosteroids, nonsteroidal anti-inflammatory drugs (NSAIDs), and conventional synthetic disease-modifying antirheumatic drugs (csDMARDs).

\section{Epidemiology of ASCVD in Patients with AIRDs}

Cumulative evidence has indicated that the rate of subclinical atherosclerosis is higher in patients with AIRDs than in age- and sex-matched healthy control individuals [8,60-62]. AIRD-related ASCVD [4] has been documented in patients with RA [63,64], SLE [28,65,66], SSc [67], PM/DMtis [68], and pSS [69,70]. If ASCVD is present, the mortality rate is significantly higher in patients with AIRDs than in those without AIRDs [71,72]. ASCVD is the leading cause of mortality in patients with RA [73]. SLE-associated mortality was originally believed to appear in a bimodal pattern, with an early peak attributable to active lupus and a later peak attributable to ASCVD [5,74]. The bimodal pattern was later flattened after Cervera et al. [75] reported that ASCVD could occur at any time during the disease course. These findings strongly indicate the importance of early screening and intervention for ASCVD in patients with AIRDs.

\section{Electronegative LDL and Its Atherogenicity}

Freshly isolated human plasma L5 and LDL (-) are highly atherogenic. They are treated to prevent oxidation during isolation, affirming that they are the naturally occurring LDL culprits responsible for atherosclerosis development and ASCVD progression.

\subsection{The Atherogenic Mechanisms of Electronegative LDL}

L5 was isolated for the first time from human plasma in $2003[33,76]$ and was shown to inhibit the transcription of the pro-survival gene fibroblast growth factor-2 (FGF-2) in arterial ECs through an Akt-mediated autoregulatory loop, thereby disrupting mitochondrial stability and inducing apoptosis [76]. Furthermore, neutralizing the PAF receptor (PAFR) significantly attenuated the L5-induced downregulation of FGF2 and the concomitant apoptosis of ECs, suggesting that L5 signals in part through PAFR [76,77]. Although L5 is not an oxidized LDL (oxLDL) entity, it shares many functional properties with experimentally prepared oxLDL. Similarly, to oxLDL, L5 stimulates the p53-dependent activation of the proapoptotic protein Bax, leading to the apoptosis of differentiated endothelial progenitor cells (EPCs) [78]. L5, which is increased in the plasma of chronic smokers, impairs EPC differentiation by inhibiting Akt phosphorylation via LOX-1 [31].

The atherogenicity of L5 can be attributed to the multiple stress pathways it induces in vascular ECs [79]. By downregulating the expression of the endoplasmic reticulum (ER) chaperone proteins ORP150, Grp94, and Grp58, L5 induces ER stress by suppressing mitochondrial proteins Prdx3 and ATP synthase and decreases the mitochondrial membrane potential to result in mitochondrial dysfunction [79]. Additionally, L5 upregulates heterogeneous nuclear ribonucleoproteins (hnRNP) $\mathrm{C} 1 / \mathrm{C} 2$ to promote macrophage recruitment and monocyte chemoattractant protein 1 (MCP-1) to accelerate inflammation [79]. Of importance, L5 upregulates vascular endothelial growth factor (VEGF) to facilitate inflammatory angiogenesis and downregulates FGF-2 transcription to inhibit compensatory angiogenesis [76,79-81]. Increased plasma C-reactive protein (CRP) levels are associated with the occurrence and severity of acute coronary syndrome [82]. By augmenting CRP expression in vascular ECs, L5 further intensifies its proinflammatory property [83].

In ECs, L5 selectively downregulates mitochondria-stabilizing Bcl-2 and upregulates mitochondria-destabilizing Bax and Bad proteins [84]. Exposure of differentiated EPCs to L5 also results in an increased transfer of mitochondria-derived superoxide anion to 
p53, which stimulates a conformational change in Bax that promotes its translocation to the mitochondria, resulting in the apoptosis of these cells [78].

Daily intravenous injection of human L5 into C57B6/J mice during a course of four weeks can induce aortic endothelial senescence accompanied by $\gamma \mathrm{H} 2 \mathrm{AX}$ deposition and DNA damage [85]. In cultured human aortic ECs, L5 can augment mitochondrial oxygen consumption and free radical production, leading to ATM activation, nuclear $\gamma \mathrm{H} 2 \mathrm{AX}$ deposition, Chk2 phosphorylation, and TP53 stabilization. L5 also decreases human telomerase reverse transcriptase (hTERT) protein levels and activity. In conclusion, L5 may promote mitochondrial free radical production and activate the DNA damage response to induce premature vascular endothelial senescence that leads to atherosclerosis.

An alternative signaling pathway of LDL (-) in monocytes and macrophages is through its binding to the TLR4/CD14 complex [55]. The binding of LDL (-) to CD14 signals the TLR4 and PI3K/Akt pathway, leading to the activation of nuclear factor-kB (NF-kB), activator protein-1 (AP-1), and cAMP response element-binding protein (CREB) nuclear transcription factors and the subsequent release of numerous cytokines [54]. In this context, LDL (-) activates the inflammasome, acting as a priming signal for IL-1 $\beta$ secretion and inducing the expression of pro-IL-1 $\beta$ and NLRP3 receptor [53].

\subsection{The Assocation of Electronegative LDL with ASCVD in Patients with AIRDs}

In three comprehensive studies, researchers have recently shown that circulating L5 levels are significantly increased in patients with RA or SLE whose plasma LDL-C levels are equal to or lower than those of healthy control individuals $[56,57,86]$. In a cohort of patients with RA, the plasma L5\% and L5 concentration were significantly higher in those with subclinical atherosclerosis than in those without it, despite similar LDL-C levels among all the study participants [56]. The plasma L5\% and L5 concentration were also positively correlated with the extent of carotid artery atherosclerosis reflected by the intimamedia thickness (IMT), disease activity score, and 10-year ASCVD risk score [56]. Further investigation revealed that $\mathrm{L} 5$ contributes to atherogenesis by augmenting macrophage foam cell formation, upregulating integrin CD11c expression, and enhancing inflammatory mediators including IL-6, IL-8, and tumor necrosis factor (TNF)- $\alpha$ [86]. These findings provide a mechanistic link between L5 and ASCVD development and clinical manifestations $[56,57,79,86]$. Most importantly, both L5\% and L5 concentration declined significantly after six months of DMARD therapy in RA patients [56], suggesting the dynamic and reversible nature of L5 formation. SLE is a systemic vascular disease that mostly affects young females [87]. The rapid progression of ASCVD in patients with SLE often leads to accelerated vascular aging and death that cannot be explained by conventional risk stratification in this age-and-sex group $[2,28,65]$. Similar to the scenario of patients with RA, patients with SLE also have a significantly higher L5\% and L5 concentration in circulation than do healthy control individuals despite patients with SLE having a plasma LDL-C level lower than that of control individuals [57]. In patients with SLE, increased L5\% correlates positively with mean blood pressure, IMT, pulse wave velocity, and blood levels of CD16+ monocytes and CX3CL1 cytokines [57]. Both L5 and the total LDL of patients with SLE have a high content of lysophosphatidylcholine (LPC) and platelet-activating factor (PAF). When administered to young $A p o E^{-/-}$mice, L5 and total LDL of patients with SLE can induce increases in plasma CX3CL1, aortic fatty-streak areas, aortic vascular aging, and macrophage infiltration into the aortic wall [57]. As expected, LPC exerts similar effects in vivo, whereas LDL from control individuals has negligible effects. In vitro, synthetic PAF and LPC can also induce CD16 expression in human monocytes and monocyte-EC adhesion, as does the lipid moiety of L5 in patients with SLE [57]. Thus, plasma L5 levels are increased in both patients with RA and those with SLE, thereby contributing to their accelerated atherosclerosis. Increased plasma L5 levels are also associated with an increased risk of ASCVD in patients with various other clinical diagnoses, including patients with uremia [43], ischemic peripheral arterial disease [44], or asymptomatic type 2 DM [39,40]. 
The risk of ASCVD in patients with asymptomatic type $2 \mathrm{DM}$ is equivalent to that in patients with RA [88].

\subsection{Combined Atherogenicity of Electronegative VLDL and LDL}

Triglyceride-rich lipoproteins, very low-density lipoprotein (VLDL) in particular, may exert atherogenic effects both directly and as a precursor of LDL. VLDL can also be chromatographically divided into subfractions with increasing electronegativity (V1-V5); the most electronegative subfraction, V5, is more toxic in ECs than L5 is at an equal concentration [89]. Notably, the combined electronegativity of L5 and V5 is significantly greater in individuals with a high risk of ASCVD than in those with a low risk of CHD [42]. In $A p o E^{-/-}$mice, the combined increased electronegativity of LDL and VLDL is accompanied by increased lipid accumulation and cellular senescence in the aorta, further substantiating their contribution to ASCVD [42].

\section{Role of LOX-1 in Electronegative LDL Signaling}

Liquid chromatography/mass spectrometry $\left(\mathrm{LC} / \mathrm{MS}^{\mathrm{E}}\right)$ analysis revealed that $\mathrm{L1}$ 's protein framework is composed of $99 \%$ apoB100 with trace amounts of other proteins, whereas L5 contains $60 \%$ apoB100 with higher amounts of apo(a), apoE, apoAI, and apoCIII than does L1. In contrast to L1, which has an isoelectric point (pI) of 6.620, L5 has a pI of 5.5 or less, which contributes to its electronegativity, rendering it unrecognizable by LDLR [90]. LOX-1, originally discovered by Sawamura et al. [91] in 1997, is a 50-kDa type II membrane protein of the C-type lectin family. An important scavenger receptor, LOX-1 exhibits binding activity for multiple ligands, including oxidized LDL (ox-LDL), polyanionic chemicals, anionic phospholipids, cellular ligands (apoptotic/aged cells, activated platelets, and bacteria), and bile salt-dependent lipase [92,93]. After being internalized via LOX-1, L5 exerts its signaling in vascular ECs and monocytes [50-54,84,90].

In $A p o E^{-/-}$mice, the specific overexpression of LOX-1 in the endothelium promotes atherosclerosis and inflammation [94]. High-cholesterol diet-induced plaque formation and proinflammatory signals can be reduced by deleting the LOX-1 gene [95]. LOX-1 is also a sensor of danger signals [96] involved in reactive oxygen species generation, which leads to NLRP3 inflammasome activation [97]. In addition, the binding of L5 or LDL $(-)$ to LOX-1 leads to intracellular signaling and activates multiple downstream events that are critical steps in atherosclerosis. Recent studies have revealed that LDL (-) from patients with STEMI could induce the production of IL-1 $\beta$, granulocyte colony-stimulating factor (G-CSF), and granulocyte/monocyte (GM)-CSF through a LOX-1-dependent pathway $[98,99]$ and that the atherogenic and proinflammatory responses elicited by LDL $(-)$ could be offset by blocking LOX-1 with a neutralizing antibody or shRNA knockdown [98]. Moreover, increased LOX-1 expression has been observed in human atherosclerotic lesions and in experimental animal models $[100,101]$, supporting a crucial role of LOX-1 in atherosclerosis.

\subsection{The Potential Atherogenic Role of LOX-1 in Patients with AIRDs}

The evidence that LOX-1 plays a role in AIRD-associated ASCVD is substantiated by the finding that plasma from patients with RA can upregulate LOX-1 expression in human macrophages [102]. In addition, CRP can enhance endothelial LOX-1 expression [103]. CRP and LOX-1 may form a positive feedback loop with L5 in atherogenesis, whereby increased levels of atherogenic LDL in patients with cardiovascular risks induce ECs to express CRP, which may in turn increase the expression of LOX-1 to promote the uptake of electronegative LDL into ECs [104].

A recent study confirmed that plasma L5 but not L1 from patients with both RA and subclinical atherosclerosis can enhance LOX-1 expression in macrophages [56]. In addition, LOX-1 expression levels in patients with RA positively correlate with plasma L5\% or L5 concentrations and are significantly associated with 10-year ASCVD risk scores [56]. Another study showed that perturbations in plasma lipid content can activate LOX-1 
expression and promote inflammatory responses, suggesting that LOX-1 is a potential driver of ASCVD risk in patients with SLE [105]. LOX-1 expression can be upregulated by other inflammatory mediators [84], and the binding of L5 to LOX-1 leads to the feedforward elevation of LOX-1 expression [56], further promoting subsequent atherogenic and inflammatory responses.

\subsection{Atherogenic Signaling of Electronegative LDL and LOX-1 in Patients with AIRDs}

A schematic summary of the pathogenic role of electronegative LDL and LOX-1 signaling in AIRD-related ASCVD is shown in Figure 1. The emergence of ASCVD in patients with AIRDs is believed to result from complex interactions among traditional cardiovascular risk factors, disease-specific factors, disease-related inflammatory mediators, and the medications used. Increased levels of electronegative LDL in patients with diabetes [37-39] may be produced by lipolysis, generating an increased level of non-esterified fatty acid (NEFA) [33]. Cigarette smoking promotes a significant increase in the production of L5, contributing to smoking-associated ASCVD via LOX-1 [31,106]. Moreover, rabbits fed an atherogenic diet were shown to produce highly proinflammatory LDL (-) [107]. The high affinity of LDL (-) for LOX-1 but low affinity for LDLR may be explained by its high NEFA content [108], its high degree of aggregation [109], and the presence of an abnormal conformation of apoB100 [110]. The L5 and LDL (-) signaling pathways mediated by LOX-1 provide further insight into the pathogenesis of ASCVD and may represent a therapeutic target for patients with AIRDs.

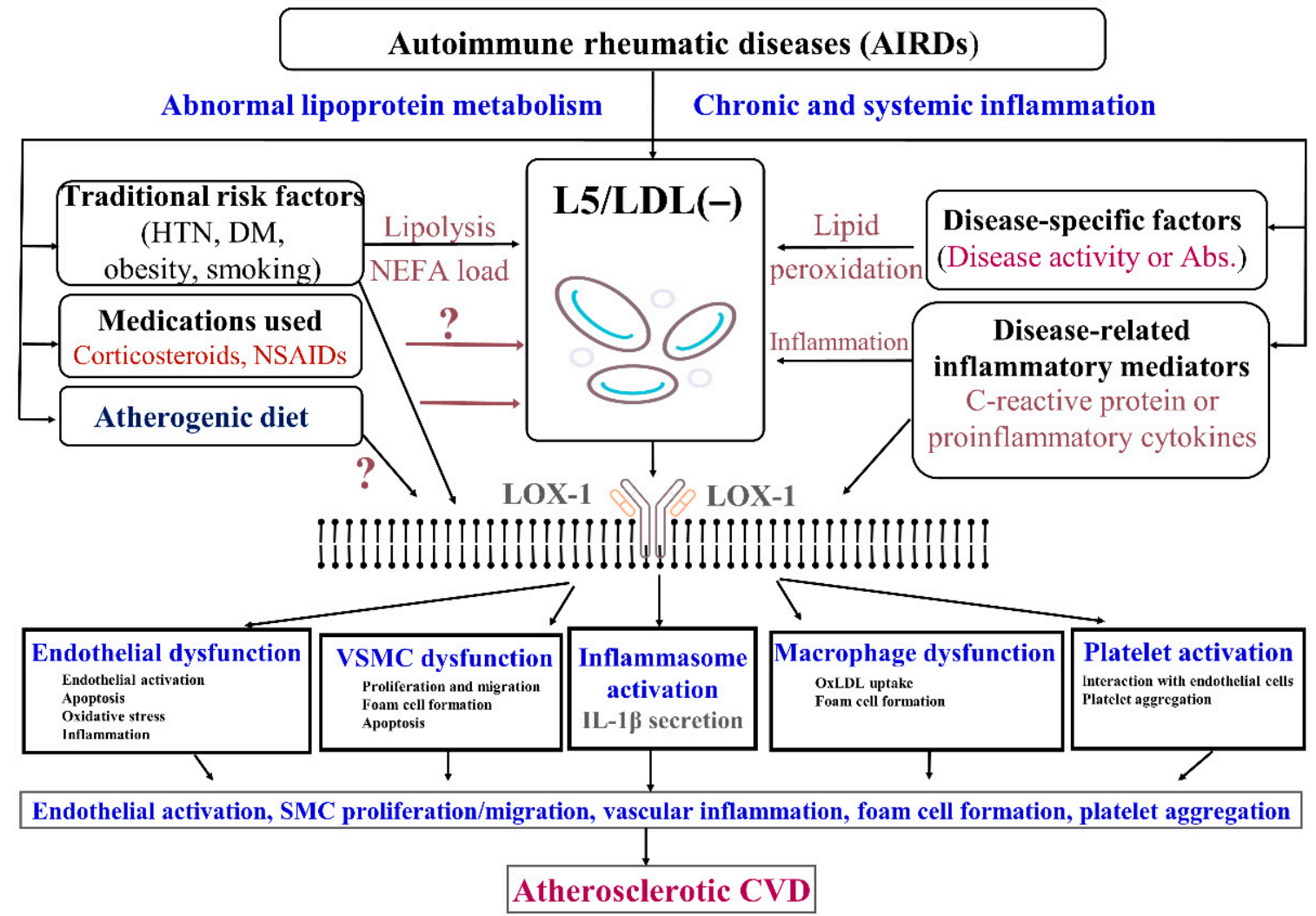

Figure 1. The probable atherogenic role of electronegative LDL (LDL(-)/L5) in patients with AIRDs. The increased levels of LDL (-) may be produced by lipolysis with non-esterified fatty acid (NEFA) loading in patients with diabetes. Cigarette smoking is associated with L5 formation and LOX-1-induced atherosclerosis. C-reactive protein induces LOX-1 expression. L5/LDL (-) and the LOX-1 signaling pathway lead to atherogenesis, vascular inflammation, and platelet activation/aggregation. LDL: low-density lipoprotein; LOX-1: lectin-like oxidized low-density lipoprotein receptor 1; HTN: hypertension; DM: diabetes mellitus; NSAIDs: nonsteroidal anti-inflammatory drugs; Abs.: autoantibodies; oxLDL: oxidized LDL; IL-1 $\beta$ : interleukin $1 \beta$; CVD: cardiovascular disease. 


\section{Proposed Therapeutic Strategies for Targeting ASCVD in Patients with AIRDs}

Epidemiologic studies have shown increased morbidity and mortality rates due to ASCVD in patients with AIRDs [4,39-47,51], suggesting the importance of screening and preventive strategies for ASCVD, as well as its management. Although there is a paucity of consensus or randomized studies regarding therapeutic strategies for ASCVD in AIRDs, both the American College of Rheumatology (ACR) and the European League Against Rheumatism (EULAR) recommendations emphasize that patients with AIRDs should undergo risk factor monitoring, CVD risk modification, and dyslipidemia therapy, if needed [111,112].

\subsection{Modifications of Traditional CVD Risk Factors}

Given that cigarette smoking is implicated in L5-LOX-1 signaling pathway-related atherosclerosis $[31,106]$ and that smoking cessation could reduce an independent ASCVD risk marker (i.e., the LOX index) [113], smoking cessation should be a priority. Avoidance of intense aerobic exercise is recommended because it may increase the NEFA content of LDL (-) [114]. Considering that an atherogenic diet induces LDL (-)-related inflammation [107], replacing it with the Mediterranean diet may reduce ASCVD risk in patients with AIRDs [115].

\subsection{Tight Control of Disease Activity and the Adjustment of Medications}

Given that AIRD-related immune dysregulation has an important role in premature atherosclerosis, the control of disease activity is essential. In patients with AIRDs, ASCVD risk is significantly associated with acute-phase reactants, inflammatory cytokines, autoantibody positivity, and specific $\mathrm{T}$ cell subsets $[116,117]$. The acute-phase reactant CRP in patients with AIRDs can enhance endothelial LOX-1 expression [103]. Chang et al. [56] also revealed a relationship between the plasma L5 proportion and the RA disease activity. The inflammatory mechanisms in AIRDs may intensify oxidative stress, triggering a broad range of proatherogenic lipid changes [118]. According to the EULAR guidelines [111,112], adequate control of disease activity reduces the risk of ASCVD in patients with AIRDs. Given the pathogenic role of proinflammatory cytokines in AIRD-related atherosclerosis, tight control of disease activity with biologic DMARDs, including TNF- $\alpha$ inhibitors, IL-6 inhibitors, and IL-17 inhibitors, may reduce the risk of ASCVD [119-121].

Increasing evidence has indicated that corticosteroids are associated with hypertension and dyslipidemia [122] and that nonsteroidal NSAIDs may adversely affect cardiovascular outcomes [123]. The EULAR guidelines recommend using the lowest dose of corticosteroids and prescribing NSAIDs with caution [111,112]. In contrast, recent studies revealed a beneficial effect of hydroxychloroquine (HCQ) on cardiovascular outcomes in patients with RA $[124,125]$. Other csDMARDs, such as methotrexate, could also reduce ASCVD risk [126].

\subsection{Lipid-Lowering Therapy}

Although cardiovascular interventional trials have not been performed specifically in patients with AIRDs, statins are the preferred therapeutic agent for dyslipidemia. Statin therapy could reduce the proportion of LDL (-) and attenuate inflammation in patients with hyperlipidemia $[127,128]$. Simvastatin therapy improves the affinity of LDL (-) for the LDLR in parallel with a decrease in the proportion of LDL (-) [127]. Given a bidirectional link between LOX-1 and PCSK9, especially in an inflammatory status [129], a PCSK9 inhibitor could reduce LOX-1 expression. L5 is a promising marker for predicting ASCVD $[56,57,86]$. The therapeutic goal of controlling L5 should be to lower its plasma concentration below $1.7 \mathrm{mg} / \mathrm{dL}$. If the $\mathrm{L} 5$ concentration is higher than $1.7 \mathrm{mg} / \mathrm{dL}$, a lipidlowering treatment, such as statins or PCSK9 inhibitors, may be required regardless of the absolute LDL level [130]. 


\subsection{Potential Therapeutic Strategy Targeting Electronegative LDL and LOX-1 Pathway}

Given that LOX-1 is a multiligand and multifunctional receptor underlying cardiovascular dysfunction and ASCVD [92-96,105], a therapy targeting LOX-1 is promising as a treatment for atherosclerosis and vasculopathy [131]. MicroRNAs, which are short noncoding RNAs, have been recently identified as immune regulators that post-transcriptionally repress mRNA expression. Recent studies have revealed that microRNA let-7g and microRNA-98 may target LOX-1 as a therapy for atherosclerosis [132,133]. In addition, the transcription factor NF- $\mathrm{KB}$ is involved in the development and progression of both vascular inflammation and ASCVD [134]. Interestingly, NF-kB and sirletin-1 feature the characteristics of antagonistic crosstalk [135]. Sirletin-1 drives anti-inflammatory responses and enhances the resolution of vascular inflammation. Based on the findings of previous studies, meta-analyses, reviews, recommendations, and our results, we propose a potential therapeutic strategy with an emphasis on targeting the L5/LDL (-) and LOX-1 pathway in patients with AIRDs (Figure 2).

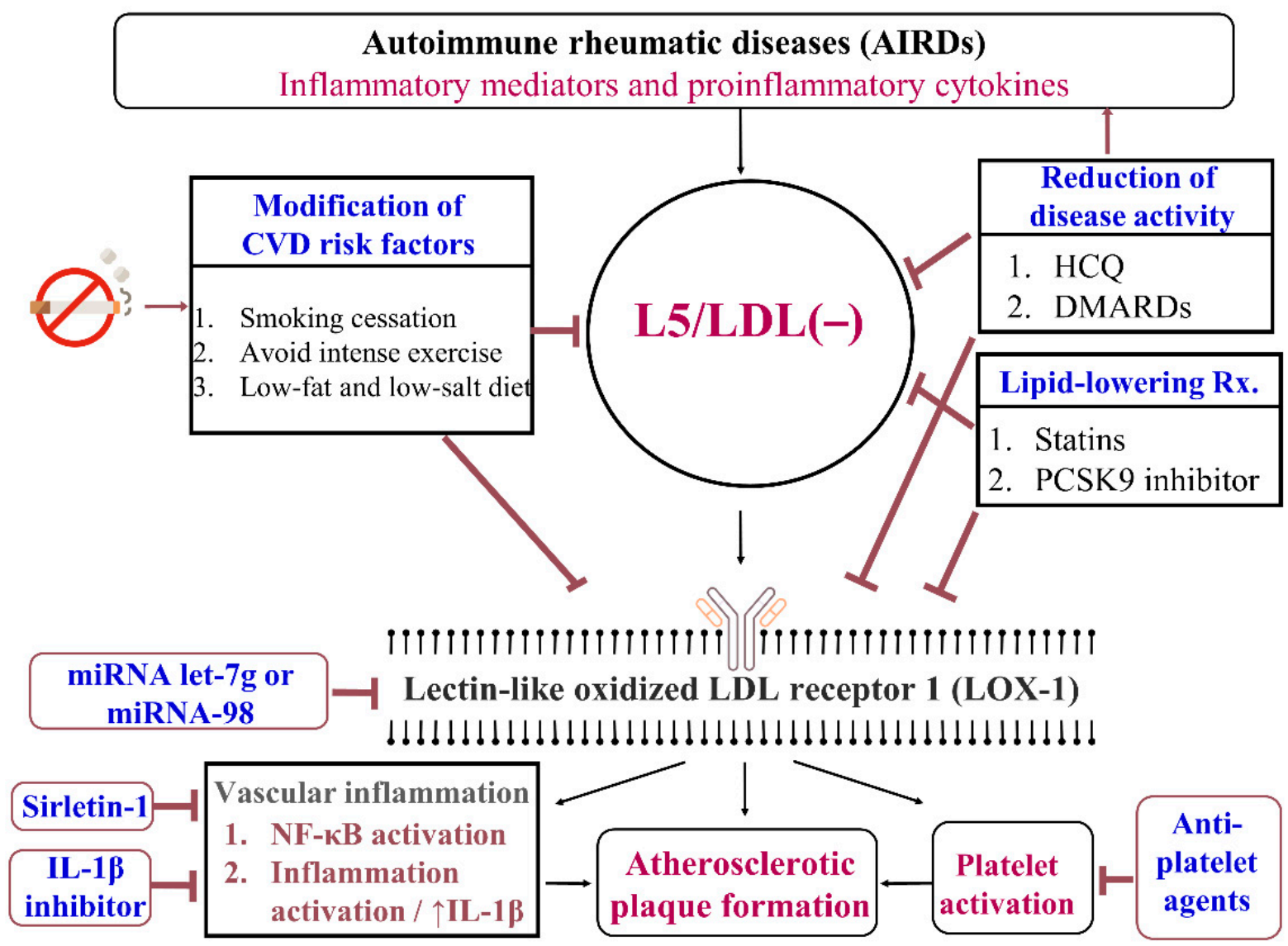

Figure 2. A potential therapeutic strategy for the targeting L5/LDL(-) and LOX-1 pathway in patients with AIRDs. Major therapeutic strategies include modifications of the traditional CVD risk factors; control of AIRD activity; and the use of lipid-lowering agents, cytokine-targeting agents, and LOX-1-targeting therapy. CVD: cardiovascular disease; LDL: low-density lipoprotein; HCQ: hydroxychloroquine; DMARDs: disease-modifying anti-rheumatic drugs; PCSK9: proprotein convertase subtilisin/kexin type 9; miRNA: microRNA; NF-kB: nuclear factor-kB; IL-1 $\beta$ : interleukin $1 \beta$. 


\section{Conclusions}

Accelerated atherosclerosis with an increased risk of ASCVD is well-documented in patients with AIRDs. Furthermore, cumulative evidence has indicated that the L5/LDL $(-)$ and LOX-1 signaling pathway contributes to atherogenicity. We propose probable mechanisms behind this signaling in the pathogenesis of AIRD-related ASCVD and a potential therapeutic strategy targeting L5/LDL (-) and LOX-1 signaling. Regularly updating these pathologic mechanisms and therapeutic strategies will be critical as new evidence emerges.

Author Contributions: Conceptualization, C.-H.C. and D.-Y.C.; methodology, D.-Y.C. and C.-H.C.; software, D.-Y.C. and C.-H.C.; validation, D.-Y.C., T.S., R.A.F.D., J.L.S.-Q. and C.-H.C.; formal analysis, C.-H.C.; investigation, C.-H.C.; resources, C.-H.C.; data curation, D.-Y.C. and C.-H.C.; writingoriginal draft preparation, D.-Y.C.; writing-review and editing, C.-H.C.; visualization, D.-Y.C., T.S., R.A.F.D., J.L.S.-Q. and C.-H.C.; supervision, C.-H.C.; project administration, C.-H.C.; funding acquisition, C.-H.C. and D.-Y.C. All authors have read and agreed to the published version of the manuscript.

Funding: This work was supported by the Vascular and Medicinal Research Fund, Texas Heart Institute, \#765-64050, Houston, TX, USA, a grant (MOST 107-2314-B-039-053-MY3) from the Ministry of Science and Technology, Taiwan, and PI16/00471 from Instituto de Salud Carlos III, Spanish Ministry of Health (co-financed by the European Regional Development Fund).

Institutional Review Board Statement: Not applicable.

Informed Consent Statement: Not applicable.

Data Availability Statement: Not applicable.

Acknowledgments: The authors thank Nicole Stancel, ELS(D) of the Department of Scientific Publications at Texas Heart Institute in Houston, Texas, for manuscript editing.

Conflicts of Interest: The authors declare no conflict of interest.

\section{References}

1. Libby, P. Inflammation in Atherosclerosis. Arter. Thromb. Vasc. Biol. 2012, 32, 2045-2051. [CrossRef]

2. Manzi, S.; Meilahn, E.N.; Rairie, J.E.; Conte, C.G.; Medsger, T.A.; Jansen-McWilliams, L.; D'Agostino, R.B.; Kuller, L.H. Agespecific Incidence Rates of Myocardial Infarction and Angina in Women with Systemic Lupus Erythematosus: Comparison with the Framingham Study. Am. J. Epidemiol. 1997, 145, 408-415. [CrossRef]

3. Tyrrell, P.N.; Beyene, J.; Feldman, B.M.; McCrindle, B.W.; Silverman, E.D.; Bradley, T.J. Rheumatic disease and carotid intimamedia thickness: A systematic review and meta-analysis. Arter. Thromb. Vasc. Biol. 2010, 30, 1014-1026. [CrossRef] [PubMed]

4. Hollan, I.; Meroni, P.L.; Ahearn, J.M.; Tervaert, J.C.; Curran, S.; Goodyear, C.S.; Hestad, K.A.; Kahaleh, B.; Riggio, M.; Shields, K.; et al. Cardiovascular disease in autoimmune rheumatic diseases. Autoimmun. Rev. 2013, 12, 1004-1015. [CrossRef] [PubMed]

5. Nurmohamed, M.T.; Heslinga, M.; Kitas, G.D. Cardiovascular comorbidity in rheumatic diseases. Nat. Rev. Rheumatol. 2015, 11, 693-704. [CrossRef] [PubMed]

6. Symmons, D.P.M.; Gabriel, S.E. Epidemiology of CVD in rheumatic disease, with a focus on RA and SLE. Nat. Rev. Rheumatol. 2011, 7, 399-408. [CrossRef]

7. Atzeni, F.; Nucera, V.; Gerratana, E.; Fiorenza, A.; Gianturco, L.; Corda, M.; Sarzi-Puttini, P. Cardiovascular Consequences of Autoimmune Rheumatic Diseases. Curr. Vasc. Pharmacol. 2020, 18, 566-579. [CrossRef] [PubMed]

8. Schirmer, M.; Dejaco, C.; Duftner, C. Advances in the evaluation and classification of chronic inflammatory rheumatic diseases. Discov. Med. 2012, 13, 299-304. [PubMed]

9. Esdaile, J.M.; Abrahamowicz, M.; Grodzicky, T.; Li, Y.; Panaritis, C.; Berger, R.D.; Côté, R.; Grover, S.A.; Fortin, P.R.; Clarke, A.E.; et al. Traditional Framingham risk factors fail to fully account for accelerated atherosclerosis in systemic lupus erythematosus. Arthritis Rheum. 2001, 44, 2331-2337. [CrossRef]

10. Svenungsson, E.; Fei, G.-Z.; Jensen-Urstad, K.; De Faire, U.; Hamsten, A.; Frostegard, J. TNF- $\alpha$ : A link between hypertriglyceridaemia and inflammation in SLE patients with cardiovascular disease. Lupus 2003, 12, 454-461. [CrossRef]

11. Rho, Y.H.; Chung, C.P.; Oeser, A.; Solus, J.; Asanuma, Y.; Sokka, T.; Pincus, T.; Raggi, P.; Gebretsadik, T.; Shintani, A.; et al. Inflammatory mediators and premature coronary atherosclerosis in rheumatoid arthritis. Arthritis Rheum. 2009, 61, 1580-1585. [CrossRef]

12. Im, C.H.; Kim, N.R.; Kang, J.W.; Kim, J.H.; Bae, G.B.; Nam, E.J.; Kang, Y.M. Inflammatory burden interacts with conventional cardiovascular risk factors for carotid plaque formation in rheumatoid arthritis. Rheumatology 2014, 54, 808-815. [CrossRef] 
13. Ambrosino, P.; Lupoli, R.; Di Minno, A.; Tasso, M.; Peluso, R.; Di Minno, M.N.D. Subclinical atherosclerosis in patients with rheumatoid arthritis. Thromb. Haemost. 2015, 113, 916-930. [CrossRef] [PubMed]

14. McKellar, G.E.; McCarey, D.W.; Sattar, N.; McInnes, I.B. Role for TNF in atherosclerosis? Lessons from autoimmune disease. Nat. Rev. Cardiol. 2009, 6, 410-417. [CrossRef]

15. Asanuma, Y.; Chung, C.P.; Oeser, A.; Shintani, A.; Stanley, E.; Raggi, P.; Stein, C.M. Increased concentration of proatherogenic inflammatory cytokines in systemic lupus erythematosus: Relationship to cardiovascular risk factors. J. Rheumatol. 2006, 33, 539-545. [PubMed]

16. Skaggs, B.J.; Hahn, B.H.; McMahon, M. Accelerated atherosclerosis in patients with SLE-mechanisms and management. Nat. Rev. Rheumatol. 2012, 8, 214-223. [CrossRef]

17. Mahmoudi, M.; Aslani, S.; Fadaei, R.; Jamshidi, A.R. New insights to the mechanisms underlying atherosclerosis in rheumatoid arthritis. Int. J. Rheum. Dis. 2017, 20, 287-297. [CrossRef] [PubMed]

18. Nezosa, A.; Evangelopoulosb, M.E.; Clio, P.; Mavragani, C.P. Genetic contributors and soluble mediators in prediction of autoimmune comorbidity. J. Autoimmun. 2019, 104, 102317. [CrossRef]

19. Leonard, D.; Svenungsson, E.; Sandling, J.K.; Berggren, O.; Jönsen, A.; Bengtsson, C.; Wang, C.; Jensen-Urstad, K.; Granstam, S.O.; Bengtsson, A.A.; et al. Coronary aheart disease in systemic lupus erythematosus is associated with interferon regulatory factor-8 variants. Circ. Cardiovasc. Genet. 2013, 6, 255-263. [CrossRef] [PubMed]

20. Øhlenschlæger, T.; Garred, P.; Madsen, H.O.; Jacobsen, S. Mannose-Binding Lectin Variant Alleles and the Risk of Arterial Thrombosis in Systemic Lupus Erythematosus. N. Engl. J. Med. 2004, 351, 260-267. [CrossRef]

21. Leonard, D.; Svenungsson, E.; Dahlqvist, J.; Alexsson, A.; Ärlestig, L.; Taylor, K.E.; Sandling, J.K.; Bengtsson, C.; Frodlund, M.; Jönsen, A.; et al. Novel gene variants associated with cardiovascular disease in systemic lupus erythematosus and rheumatoid arthritis. Ann. Rheum. Dis. 2018, 77, 1063-1069. [CrossRef] [PubMed]

22. Maehlen, M.T.; Provan, S.A.; de Rooy, D.P.; van der Helm-van, A.H.; Krabben, A.; Saxne, T.; Lindqvist, E.; Semb, A.G.; Uhlig, T.; van der Heijde, D.; et al. Associations between APOE Genotypes and Disease Susceptibility, Joint Damage and Lipid Levels in Patients with Rheumatoid Arthritis. PLoS ONE 2013, 8, e60970. [CrossRef]

23. Arnett, D.K.; Blumenthal, R.S.; Albert, M.A.; Buroker, A.B.; Goldberger, Z.D.; Hahn, E.J.; Himmelfarb, C.D.; Khera, A.; Lloyd-Jones, D.; McEvoy, J.W.; et al. 2019 ACC/AHA guideline on the primary prevention of cardiovascular disease: Executive summary: A report of the American College of Cardiology/American Heart Association Task Force on Clinical Practice Guidelines. J. Am. Coll. Cardiol. 2019, 74, 1376-1414. [CrossRef] [PubMed]

24. Boyer, J.-F.; Gourraud, P.-A.; Cantagrel, A.; Davignon, J.-L.; Constantin, A. Traditional cardiovascular risk factors in rheumatoid arthritis: A meta-analysis. Jt. Bone Spine 2011, 78, 179-183. [CrossRef]

25. Nuttall, S.L.; Heaton, S.; Piper, M.K.; Martin, U.; Gordon, C. Cardiovascular risk in systemic lupus erythematosus-evidence of increased oxidative stress and dyslipidaemia. Rheumatology 2003, 42, 758-762. [CrossRef]

26. Abdou, M.M.S.; El Desouky, S.M.; El Kaffas, K.M.H.; Hassan, A.M.A. Premature atherosclerosis in systemic sclerosis patients: Its relation to disease parameters and to traditional risk factors. Int. J. Rheum. Dis. 2016, 20, 383-389. [CrossRef]

27. Quevedo-Abeledo, J.C.; Rúa-Figueroa, Í.; Sánchez-Pérez, H.; Naranjo, A.; De Armas-Rillo, L.; Tejera-Segura, B.; Lopez-Mejías, R.; González-Gay, M.; Ferraz-Amaro, I. Comparable effects of traditional cardiovascular risk factors on subclinical atherosclerosis in systemic lupus erythematosus and rheumatoid arthritis. Clin. Exp. Rheumatol. 2020, 38, 917-924. [PubMed]

28. Roman, M.J.; Shanker, B.-A.; Davis, A.; Lockshin, M.D.; Sammaritano, L.; Simantov, R.; Crow, M.K.; Schwartz, J.E.; Paget, S.A.; Devereux, R.B.; et al. Prevalence and Correlates of Accelerated Atherosclerosis in Systemic Lupus Erythematosus. N. Engl. J. Med. 2003, 349, 2399-2406. [CrossRef]

29. Semb, A.G.; Kvien, T.K.; Aastveit, A.H.; Jungner, I.; Pedersen, T.R.; Walldius, G.; Holme, I. Lipids, myocardial infarction and ischaemic stroke in patients with rheumatoid arthritis in the Apolipoprotein-related Mortality RISk (AMORIS) Study. Ann. Rheum. Dis. 2010, 69, 1996-2001. [CrossRef]

30. Kovanen, P.T.; Pentikäinen, M.O. Circulating lipoproteins as proinflammatory and anti-inflammatory particles in atherogenesis. Curr. Opin. Lipidol. 2003, 14, 411-419. [CrossRef]

31. Tang, D.; Lu, J.; Walterscheid, J.P.; Chen, H.-H.; Engler, D.A.; Sawamura, T.; Chang, P.-Y.; Safi, H.J.; Yang, C.-Y.; Chen, C.-H. Electronegative LDL circulating in smokers impairs endothelial progenitor cell differentiation by inhibiting Akt phosphorylation via LOX-1. J. Lipid Res. 2008, 49, 33-47. [CrossRef]

32. Avogaro, P.; Bon, G.B.; Cazzolato, G. Presence of a modified low density lipoprotein in humans. Arteriosclerosis 1988, 8, 79-87. [CrossRef]

33. Yang, C.-Y.; Raya, J.L.; Chen, H.-H.; Chen, C.-H.; Abe, Y.; Pownall, H.J.; Taylor, A.A.; Smith, C.V. Isolation, Characterization, and Functional Assessment of Oxidatively Modified Subfractions of Circulating Low-Density Lipoproteins. Arter. Thromb. Vasc. Biol. 2003, 23, 1083-1090. [CrossRef] [PubMed]

34. Sánchez-Quesada, J.L.; Villegas, S.; Ordóñez-Llanos, J. Electronegative low-density lipoprotein. A link between apolipoprotein B misfolding, lipoprotein aggregation and proteoglycan binding. Curr. Opin. Lipidol. 2012, 23, 479-486. [CrossRef]

35. Sánchez-Quesada, J.L.; Benítez, S.; Ordóñez-Llanos, J. Electronegative low-density lipoprotein. Curr. Opin. Lipidol. 2004, 15, 329-335. [CrossRef] 
36. Sanchez-Quesada, J.L.; Camacho, M.; Anton, R.; Benitez, S.; Vila, L.; Ordonez-Llanos, J. Electronegative LDL of FH subjects: Chemical characterization and induction of chemokine release from human endothelial cells. Atherosclerosis 2003, 166, 261-270. [CrossRef]

37. Sanchez-Quesada, J.L.; Benítez, S.; Pérez, A.; Wagner, A.M.; Rigla, M.; Carreras, G.; Vila, L.; Camacho, M.; Arcelus, R.; OrdóñezLlanos, J. The inflammatory properties of electronegative low-density lipoprotein from type 1 diabetic patients are related to increased platelet-activating factor acetylhydrolase activity. Diabetologia 2005, 48, 2162-2169. [CrossRef] [PubMed]

38. Yang, C.-Y.; Chen, H.-H.; Huang, M.T.; Raya, J.L.; Yang, J.-H.; Chen, C.-H.; Gaubatz, J.W.; Pownall, H.J.; Taylor, A.A.; Ballantyne, C.M.; et al. Pro-apoptotic low-density lipoprotein subfractions in type II diabetes. Atherosclerosis 2007, 193, 283-291. [CrossRef]

39. Rigla, M.; Sánchez-Quesada, J.L.; Ordóñez-Llanos, J.; Prat, T.; Caixàs, A.; Jorba, O.; Serra, J.R.; De Leiva, A.; Pérez, A. Effect of physical exercise on lipoprotein(a) and low-density lipoprotein modifications in Type 1 and Type 2 diabetic patients. Metabolism 2000, 49, 640-647. [CrossRef]

40. Tamura, K.; Haruhara, K.; Azushima, K.; Tokita, Y.; Wakui, H. Possible impact of electronegative LDL on atherosclerosis in type 2 diabetes. Atherosclerosis 2017, 265, 253-255. [CrossRef] [PubMed]

41. Tomasik, A.; Jacheć, W.; Skrzep-Poloczek, B.; Widera-Romuk, E.; Wodniecki, J.; Wojciechowska, C. Circulating electronegatively charged low-density lipoprotein in patients with angiographically documented coronary artery disease. Scand. J. Clin. Lab. Investig. 2003, 63, 259-265. [CrossRef]

42. Shen, M.-Y.; Hsu, J.-F.; Chen, F.-Y.; Lu, J.; Chang, C.-M.; Madjid, M.; Dean, J.; Dixon, R.A.F.; Shayani, S.; Chou, T.-C.; et al. Combined LDL and VLDL Electronegativity Correlates with Coronary Heart Disease Risk in Asymptomatic Individuals. J. Clin. Med. 2019, 8, 1193. [CrossRef]

43. Chang, C.-T.; Wang, G.-J.; Kuo, C.-C.; Hsieh, J.-Y.; Lee, A.-S.; Chang, C.-M.; Wang, C.-C.; Shen, M.-Y.; Huang, C.-C.; Sawamura, T.; et al. Electronegative Low-density Lipoprotein Increases Coronary Artery Disease Risk in Uremia Patients on Maintenance. Hemodialysis. Med. 2016, 95, e2265. [CrossRef]

44. Chang, C.-T.; Shen, M.-Y.; Lee, A.-S.; Wang, C.-C.; Chen, W.-Y.; Chang, C.-M.; Chang, K.-C.; Stancel, N.; Chen, C.-H. Electronegative low-density lipoprotein increases the risk of ischemic lower-extremity peripheral artery disease in uremia patients on maintenance hemodialysis. Sci. Rep. 2017, 7, 4654. [CrossRef] [PubMed]

45. Chang, P.-Y.; Chen, Y.-J.; Chang, F.-H.; Lu, J.; Huang, W.-H.; Yang, T.-C.; Lee, Y.-T.; Chang, S.-F.; Lu, S.-C.; Chen, C.-H. Aspirin protects human coronary artery endothelial cells against atherogenic electronegative LDL via an epigenetic mechanism: A novel cytoprotective role of aspirin in acute myocardial infarction. Cardiovasc. Res. 2013, 99, 137-145. [CrossRef] [PubMed]

46. Chan, H.-C.; Ke, L.-Y.; Chu, C.-S.; Lee, A.-S.; Shen, M.-Y.; Cruz, M.A.; Hsu, J.-F.; Cheng, K.-H.; Chan, H.-C.B.; Lu, J.; et al. Highly electronegative LDL from patients with ST-elevation myocardial infarction triggers platelet activation and aggregation. Blood 2013, 122, 3632-3641. [CrossRef] [PubMed]

47. Shen, M.-Y.; Chen, F.-Y.; Hsu, J.-F.; Fu, R.-H.; Chang, C.-M.; Chang, C.-T.; Liu, C.-H.; Wu, J.-R.; Lee, A.-S.; Chan, H.-C.; et al. Plasma L5 levels are elevated in ischemic stroke patients and enhance platelet aggregation. Blood 2016, 127, 1336-1345. [CrossRef] [PubMed]

48. Hsu, J.-F.; Chou, T.-C.; Lu, J.; Chen, S.-H.; Chen, F.-Y.; Chen, C.-C.; Chen, J.L.; Elayda, M.; Ballantyne, C.M.; Shayani, S.; et al. Low-Density Lipoprotein Electronegativity Is a Novel Cardiometabolic Risk Factor. PLoS ONE 2014, 9, e107340. [CrossRef]

49. Akyol, O.; Chowdhury, I.; Akyol, H.R.; Tessier, K.; Vural, H.; Akyol, S. Why are cardiovascular diseases more common among patients with severe mental illness? The potential involvement of electronegative low-density lipoprotein (LDL) L5. Med. Hypotheses 2020, 142, 109821. [CrossRef]

50. Ke, L.Y.; Chan, H.C.; Chan, H.C.; Kalu, F.C.U.; Lee, H.C.; Lin, I.L.; Jhuo, S.J.; Lai, W.T.; Tsao, C.R.; Sawamura, T.; et al. Electronegative low-density lipoprotein L5 induces adipose tissue inflammation associated with metabolic syndrome. J. Clin. Endocrinol. Metab. 2017, 102, 4615-4625. [CrossRef]

51. Yang, T.C.; Chang, P.Y.; Lu, S.C. L5-LDL from ST-elevation myocardial infarction patients induces IL-1beta production via LOX-1 and NLRP3 inflammasome activation in macrophages. Am. J. Physiol Heart Circ. Physiol 2017, 312, H265-H274. [CrossRef]

52. Ke, L.-Y.; Law, S.H.; Mishra, V.K.; Parveen, F.; Chan, H.-C.; Lu, Y.-H.; Chu, C.-S. Molecular and Cellular Mechanisms of Electronegative Lipoproteins in Cardiovascular Diseases. Biomedicines 2020, 8, 550. [CrossRef]

53. Estruch, M.; Sánchez-Quesada, J.L.; Llanos, J.O.; Benítez, S. Electronegative LDL: A Circulating Modified LDL with a Role in Inflammation. Mediat. Inflamm. 2013, 2013, 1-13. [CrossRef] [PubMed]

54. Estruch, M.; Sanchez-Quesada, J.L.; Ordoñez-Llanos, J.; Benitez, S. Inflammatory intracellular pathways activated by electronegative LDL in monocytes. Biochim. Biophys. Acta Mol. Cell Biol. Lipids 2016, 1861, 963-969. [CrossRef] [PubMed]

55. Estruch, M.; Bancells, C.; Beloki, L.; Sanchez-Quesada, J.L.; Ordóñez-Llanos, J.; Benitez, S. CD14 and TLR4 mediate cytokine release promoted by electronegative LDL in monocytes. Atherosclerosis 2013, 229, 356-362. [CrossRef] [PubMed]

56. Chang, C.-Y.; Chen, C.-H.; Chen, Y.-M.; Hsieh, T.-Y.; Li, J.-P.; Shen, M.-Y.; Lan, J.-L.; Chen, D.-Y. Association between Negatively Charged Low-Density Lipoprotein L5 and Subclinical Atherosclerosis in Rheumatoid Arthritis Patients. J. Clin. Med. 2019, 8, 177. [CrossRef]

57. Chan, H.C.; Chan, H.C.; Liang, C.J.; Lee, H.C.; Su, H.; Lee, A.S.; Shiea, J.; Tsai, W.C.; Ou, T.T.; Wu, C.C.; et al. Role of lowdensity lipoprotein in early vascular aging associated with systemic lupus erythematosus. Arthritis Rheumatol. 2020, 72, 972-984. [CrossRef] 
58. Gartshteyn, Y.; Braverman, G.; Mahtani, S.; Geraldino-Pardilla, L.; Bokhari, S.; Askanase, A. Prevalence of coronary artery calcification in young patients with SLE of predominantly Hispanic and African-American descent. Lupus Sci. Med. 2019, 6, e000330. [CrossRef]

59. Chen, Y.-R.; Hsieh, F.-I.; Chang, C.-C.; Chi, N.-F.; Wu, H.-C.; Chiou, H.-Y. The effect of rheumatoid arthritis on the risk of cerebrovascular disease and coronary artery disease in young adults. J. Chin. Med Assoc. 2018, 81, 772-780. [CrossRef]

60. Mahtta, D.; Gupta, A.; Ramsey, D.J.; Al Rifai, M.; Mehta, A.; Krittanawong, C.; Lee, M.T.; Nasir, K.; Samad, Z.; Blumenthal, R.S.; et al. Autoimmune Rheumatic Diseases and Premature Atherosclerotic Cardiovascular Disease: An Analysis From the VITAL Registry. Am. J. Med. 2020, 133, 1424-1432.e1. [CrossRef] [PubMed]

61. Dimitroulas, T.; Baniotopoulos, P.; Pagkopoulou, E.; Soulaidopoulos, S.; Nightingale, P.; Sandoo, A.; Karagiannis, A.; Douglas, K.; Sachinidis, A.; Garyfallos, A.; et al. Subclinical atherosclerosis in systemic sclerosis and rheumatoid arthritis: A comparative matched-cohort study. Rheumatol. Int. 2020, 40, 1997-2004. [CrossRef] [PubMed]

62. Wu, G.-C.; Liu, H.-R.; Leng, R.-X.; Li, X.-P.; Li, X.-M.; Pan, H.-F.; Ye, D.-Q. Subclinical atherosclerosis in patients with systemic lupus erythematosus: A systemic review and meta-analysis. Autoimmun. Rev. 2016, 15, 22-37. [CrossRef]

63. Solomon, D.H.; Avorn, J.; Katz, J.N.; Weinblatt, M.E.; Setoguchi, S.; Levin, R.; Schneeweiss, S. Immunosuppressive medications and hospitalization for cardiovascular events in patients with rheumatoid arthritis. Arthritis Rheum. 2006, 54, 3790-3798. [CrossRef] [PubMed]

64. Avina-Zubieta, J.A.; Thomas, J.; Sadatsafavi, M.; Lehman, A.J.; Lacaille, D. Risk of incident cardiovascular events in patients with rheumatoid arthritis: A meta-analysis of observational studies. Ann. Rheum. Dis. 2012, 71, 1524-1529. [CrossRef]

65. Schoenfeld, S.R.; Kasturi, S.; Costenbader, K.H. The epidemiology of atherosclerotic cardiovascular disease among patients with SLE: A systematic review. Semin. Arthritis Rheum. 2013, 43, 77-95. [CrossRef] [PubMed]

66. Kostopoulou, M.; Nikolopoulos, D.; Parodis, I.; Bertsias, G. Cardiovascular Disease in Systemic Lupus Erythematosus: Recent data on epidemiology, risk factors and prevention. Curr. Vasc. Pharmacol. 2020, 18, 549-565. [CrossRef]

67. Schiopu, E.; Au, K.M.; McMahon, M.A.; Kaplan, M.J.; Divekar, A.; Singh, R.R.; Furst, D.E.; Clements, P.J.; Ragvendra, N.; Zhao, W.; et al. Prevalence of subclinical atherosclerosis is increased in systemic sclerosis and is associated with serum proteins: A cross-sectional, controlled study of carotid ultrasound. Rheumatology 2014, 53, 704-713. [CrossRef]

68. Wang, H.; Cai, Y.; Cai, L.; Hu, Y.; Chen, X.; Deng, J. Altered Lipid Levels in Untreated Patients with Early Polymyositis. PLoS ONE 2014, 9, e89827. [CrossRef] [PubMed]

69. Bartoloni, E.; Alunno, A.; Valentini, V.; Valentini, E.; La Paglia, G.C.M.; Leone, M.C.; Cafaro, G.; Marcucci, E.; Bonifacio, A.F.; Luccioli, F; et al. The prevalence and relevance of traditional cardiovascular risk factors in primary Sjögren's syndrome. Clin. Exp. Rheumatol. 2018, 36, 113-120.

70. Cai, X.; Luo, J.; Wei, T.; Qin, W.; Wang, X.; Li, X. Risk of cardiovascular involvement in patients with primary Sjögren's syndrome: A large-scale cross-sectional cohort study. Acta Reum. Port. 2019, 44, 71-77.

71. Gabriel, S.E.; Michaud, K. Epidemiological studies in incidence, prevalence, mortality, and comorbidity of the rheumatic diseases. Arthritis Res. Ther. 2009, 11, 229. [CrossRef]

72. Jorge, A.M.; Lu, N.; Keller, S.F.; Rai, S.K.; Zhang, Y.; Choi, H.K. The Effect of Statin Use on Mortality in Systemic Autoimmune Rheumatic Diseases. J. Rheumatol. 2018, 45, 1689-1695. [CrossRef] [PubMed]

73. Hoek, J.V.D.; Boshuizen, H.C.; Roorda, L.D.; Tijhuis, G.J.; Nurmohamed, M.T.; Bos, G.A.M.V.D.; Dekker, J. Mortality in patients with rheumatoid arthritis: A 15-year prospective cohort study. Rheumatol. Int. 2017, 37, 487-493. [CrossRef]

74. Bartels, C.M.; Buhr, K.A.; Goldberg, J.W.; Bell, C.L.; Visekruna, M.; Nekkanti, S.; Greenlee, R.T. Mortality and Cardiovascular Burden of Systemic Lupus Erythematosus in a US Population-based Cohort. J. Rheumatol. 2014, 41, 680-687. [CrossRef] [PubMed]

75. Cervera, R.; Khamashta, M.A. Epidemiology of systemic lupus erythematosus at the change of the millennium: Lessons from the Euro-Lupus and the LUMINA projects. Lupus 2006, 15, 1-2. [CrossRef] [PubMed]

76. Chen, C.-H.; Jiang, T.; Yang, J.-H.; Jiang, W.; Lu, J.; Marathe, G.K.; Pownall, H.J.; Ballantyne, C.M.; McIntyre, T.M.; Henry, P.D.; et al. Low-Density Lipoprotein in Hypercholesterolemic Human Plasma Induces Vascular Endothelial Cell Apoptosis by Inhibiting Fibroblast Growth Factor 2 Transcription. Circulation 2003, 107, 2102-2108. [CrossRef] [PubMed]

77. Chang, P.-Y.; Lu, S.-C.; Su, T.-C.; Chou, S.-F.; Huang, W.-H.; Morrisett, J.D.; Chen, C.-H.; Liau, C.-S.; Lee, Y.-T. Lipoprotein-X reduces LDL atherogenicity in primary biliary cirrhosis by preventing LDL oxidation. J. Lipid Res. 2004, 45, 2116-2122. [CrossRef]

78. Cheng, J.; Cui, R.; Chen, C.-H.; Du, J. Oxidized Low-Density Lipoprotein Stimulates p53-Dependent Activation of Proapoptotic Bax Leading to Apoptosis of Differentiated Endothelial Progenitor Cells. Endocrinology 2007, 148, 2085-2094. [CrossRef] [PubMed]

79. Chen, C.-Y.; Hsu, H.-C.; Lee, A.-S.; Tang, D.; Chow, L.-P.; Yang, C.-Y.; Chen, H.; Lee, Y.-T.; Chen, C.-H. The Most Negatively Charged Low-Density Lipoprotein L5 Induces Stress Pathways in Vascular Endothelial Cells. J. Vasc. Res. 2012, 49, $329-341$. [CrossRef]

80. Chen, C.-H.; Walterscheid, J.P. Plaque Angiogenesis Versus Compensatory Arteriogenesis in Atherosclerosis. Circ. Res. 2006, 99, 787-789. [CrossRef] [PubMed]

81. Chen, C.-H.; Cartwright, J.J.; Li, Z.; Lou, S.; Nguyen, H.H.; Gotto, J.A.M.; Henry, P.D. Inhibitory Effects of Hypercholesterolemia and Ox-LDL on Angiogenesis-like Endothelial Growth in Rabbit Aortic Explants. Arter. Thromb. Vasc. Biol. 1997, 17, 1303-1312. [CrossRef]

82. Ridker, P.M. Clinical Application of C-Reactive Protein for Cardiovascular Disease Detection and Prevention. Circulation 2003, 107, 363-369. [CrossRef] [PubMed] 
83. Chu, C.-S.; Wang, Y.-C.; Lu, L.-S.; Walton, B.; Yilmaz, H.R.; Huang, R.Y.; Sawamura, T.; Dixon, R.A.F.; Lai, W.-T.; Chen, C.-H.; et al. Electronegative Low-Density Lipoprotein Increases C-Reactive Protein Expression in Vascular Endothelial Cells through the LOX-1 Receptor. PLoS ONE 2013, 8, e70533. [CrossRef] [PubMed]

84. Lu, J.; Yang, J.H.; Burns, A.R.; Chen, H.H.; Tang, D.; Walterscheid, J.P.; Suzuki, S.; Yang, C.Y.; Sawamura, T.; Chen, C.H. Mediation of electronegative low-density lipoprotein signaling by LOX-1: A possible mechanism of endothelial apoptosis. Circ. Res. 2009, 104, 619-627. [CrossRef] [PubMed]

85. Wang, Y.-C.; Lee, A.-S.; Lu, L.-S.; Ke, L.-Y.; Chen, W.-Y.; Dong, J.-W.; Lu, J.; Chen, Z.; Chu, C.-S.; Chan, H.-C.; et al. Human electronegative LDL induces mitochondrial dysfunction and premature senescence of vascular cells in vivo. Aging Cell 2018, 17, e12792. [CrossRef]

86. Chang, C.-K.; Chen, P.-K.; Lan, J.-L.; Chang, S.-H.; Hsieh, T.-Y.; Liao, P.-J.; Chen, C.-H.; Chen, D.-Y. Association of Electronegative LDL with Macrophage Foam Cell Formation and CD11c Expression in Rheumatoid Arthritis Patients. Int. J. Mol. Sci. 2020, 21, 5883. [CrossRef]

87. Stojan, G.; Petri, M. Epidemiology of systemic lupus erythematosus: An update. Curr. Opin. Rheumatol. 2018, 30, 144-150. [CrossRef] [PubMed]

88. Lindhardsen, J.; Ahlehoff, O.; Gislason, G.H.; Madsen, O.R.; Olesen, J.B.; Torp-Pedersen, C.; Hansen, P.R. The risk of myocardial infarction in rheumatoid arthritis and diabetes mellitus: A Danish nationwide cohort study. Ann. Rheum. Dis. 2011, 70,929-934. [CrossRef]

89. Chen, C.-H.; Lu, J.; Chen, S.-H.; Huang, R.Y.; Yilmaz, H.R.; Dong, J.; Elayda, M.A.; Dixon, R.A.; Yang, C.-Y. Effects of Electronegative VLDL on Endothelium Damage in Metabolic Syndrome. Diabetes Care 2012, 35, 648-653. [CrossRef] [PubMed]

90. Ke, L.-Y.; Engler, D.A.; Lu, J.; Matsunami, R.K.; Chan, H.-C.; Wang, G.-J.; Yang, C.-Y.; Chang, J.-G.; Chen, C.-H. Chemical composition-oriented receptor selectivity of L5, a naturally occurring atherogenic low-density lipoprotein. Pure Appl. Chem. 2011, 83, 1731-1740. [CrossRef]

91. Sawamura, T.; Kume, N.; Aoyama, T.; Moriwaki, H.; Hoshikawa, H.; Aiba, Y.; Tanaka, T.; Miwa, S.; Katsura, Y.; Kita, T.; et al. An endothelial receptor for oxidized low-density lipoprotein. Nat. Cell Biol. 1997, 386, 73-77. [CrossRef]

92. Shi, X.; Niimi, S.; Ohtani, T.; Machida, S. Characterization of residues and sequences of the carbohydrate recognition domain required for cell surface localization and ligand binding of human lectin-like oxidized LDL receptor. J. Cell Sci. 2001, 114, 1273-1282. [CrossRef]

93. Chen, Y.-H.; Lin, S.-J.; Lin, F.-Y.; Wu, T.-C.; Tsao, C.-R.; Huang, P.-H.; Liu, P.-L.; Chen, J.-W. High Glucose Impairs Early and Late Endothelial Progenitor Cells by Modifying Nitric Oxide-Related but Not Oxidative Stress-Mediated Mechanisms. Diabetes 2007, 56, 1559-1568. [CrossRef]

94. Akhmedov, A.; Rozenberg, I.; Paneni, F.; Camici, G.G.; Shi, Y.; Doerries, C.; Sledzinska, A.; Mocharla, P.; Breitenstein, A.; Lohmann, C.; et al. Endothelial overexpression of LOX-1 increases plaque formation and promotes atherosclerosis in vivo. Eur. Heart J. 2014, 35, 2839-2848. [CrossRef]

95. Mehta, J.L.; Sanada, N.; Hu, C.P.; Chen, J.; Dandapat, A.; Sugawara, F.; Satoh, H.; Inoue, K.; Kawase, Y.; Jishage, K.-I.; et al. Deletion of LOX-1 Reduces Atherogenesis in LDLR Knockout Mice Fed High Cholesterol Diet. Circ. Res. 2007, 100, 1634-1642. [CrossRef]

96. Sawamura, T.; Kakino, A.; Fujita, Y. LOX-1: A multiligand receptor at the crossroads of response to danger signals. Curr. Opin. Lipidol. 2012, 23, 439-445. [CrossRef] [PubMed]

97. Ding, Z.; Liu, S.; Wang, X.; Dai, Y.; Khaidakov, M.; Deng, X.; Fan, Y.; Xiang, D.; Mehta, J.L. LOX-1, mtDNA damage, and NLRP3 inflammasome activation in macrophages: Implications in atherogenesis. Cardiovasc. Res. 2014, 103, 619-628. [CrossRef] [PubMed]

98. Yang, T.C.; Chang, P.Y.; Kuo, T.L.; Lu, S.C. Electronegative L5-LDL induces the production of G-CSF and GM-CSF in human macrophages through LOX-1 involving NF-kappaB and ERK2 activation. Atherosclerosis 2017, 267, 1-9. [CrossRef]

99. Chang, S.-F.; Chang, P.-Y.; Chou, Y.-C.; Lu, S.-C. Electronegative LDL Induces M1 Polarization of Human Macrophages Through a LOX-1-Dependent Pathway. Inflammation 2020, 43, 1524-1535. [CrossRef] [PubMed]

100. Li, D.Y.; Chen, H.J.; Staples, E.D.; Ozaki, K.; Annex, B.; Singh, B.K.; Vermani, R.; Mehtat, J.L. Oxidized Low-Density Lipoprotein Receptor LOX-1 and Apoptosis in Human Atherosclerotic Lesions. J. Cardiovasc. Pharmacol. Ther. 2002, 7, 147-153. [CrossRef] [PubMed]

101. Shibata, M.-A.; Shibata, E.; Maemura, K.; Kondo, Y.; Harada-Shiba, M. Pathological and molecular analyses of atherosclerotic lesions in ApoE-knockout mice. Med. Mol. Morphol. 2017, 50, 130-144. [CrossRef]

102. Voloshyna, I.; Modayil, S.; Littlefield, M.J.; Belilos, E.; Belostocki, K.; Bonetti, L.; Rosenblum, G.; Carsons, S.E.; Reiss, A.B. Plasma from rheumatoid arthritis patients promotes pro-atherogenic cholesterol transport gene expression in THP-1 human macrophages. Exp. Biol. Med. 2013, 238, 1192-1197. [CrossRef]

103. Li, L.; Roumeliotis, N.; Sawamura, T.; Renier, G. C-reactive protein enhances LOX-1 expression in human aortic endothelial cells: Relevance of LOX-1 to C-reactive protein-induced endothelial dysfunction. Circ. Res. 2004, 95, 877-883. [CrossRef] [PubMed]

104. Stancel, N.; Chen, C.-C.; Ke, L.-Y.; Chu, C.-S.; Lu, J.; Sawamura, T.; Chen, C.-H. Interplay between CRP, Atherogenic LDL, and LOX-1 and Its Potential Role in the Pathogenesis of Atherosclerosis. Clin. Chem. 2016, 62, 320-327. [CrossRef] [PubMed]

105. Sagar, D.; Gaddipati, R.; Ongstad, E.L.; Bhagroo, N.; An, L.-L.; Wang, J.; Belkhodja, M.; Rahman, S.; Manna, Z.; Davis, M.A.; et al. LOX-1: A potential driver of cardiovascular risk in SLE patients. PLoS ONE 2020, 15, e0229184. [CrossRef] 
106. Takanabe-Mori, R.; Ono, K.; Wada, H.; Takaya, T.; Ura, S.; Yamakage, H.; Satoh-Asahara, N.; Shimatsu, A.; Takahashi, Y.; Fujita, M.; et al. Lectin-like oxidized low-density lipoprotein receptor-1 plays an important role in vascular inflammation in current smokers. J. Atheroscler. Thromb. 2013, 20, 585-590. [CrossRef]

107. Chang, P.-Y.; Pai, J.-H.; Lai, Y.-S.; Lu, S.-C. Electronegative LDL from Rabbits Fed with Atherogenic Diet Is Highly Proinflammatory. Mediat. Inflamm. 2019, 2019, 1-12. [CrossRef] [PubMed]

108. Benítez, S.; Villegas, V.; Bancells, C.; Jorba, O.; González-Sastre, F.; Ordóñez-Llanos, J.; Sánchez-Quesada, J.L.; Villegas, S. Impaired Binding Affinity of Electronegative Low-Density Lipoprotein (LDL) to the LDL Receptor Is Related to Nonesterified Fatty Acids and Lysophosphatidylcholine Content. Biochemistry 2004, 43, 15863-15872. [CrossRef]

109. Bancells, C.; Villegas, S.; Blanco, F.J.; Benítez, S.; Gállego, I.; Beloki, L.; Pérez-Cuellar, M.; Ordóñez-Llanos, J.; Sánchez-Quesada, J.L. Aggregated Electronegative Low Density Lipoprotein in Human Plasma Shows a High Tendency toward Phospholipolysis and Particle Fusion. J. Biol. Chem. 2010, 285, 32425-32435. [CrossRef]

110. Bancells, C.; Benítez, S.; Ordóñez-Llanos, J.; Öörni, K.; Kovanen, P.T.; Milne, R.W.; Sánchez-Quesada, J.L. Immunochemical Analysis of the Electronegative LDL Subfraction Shows That Abnormal N-terminal Apolipoprotein B Conformation Is Involved in Increased Binding to Proteoglycans. J. Biol. Chem. 2011, 286, 1125-1133. [CrossRef] [PubMed]

111. Peters, M.J.L.; Symmons, D.P.M.; McCarey, D.; Dijkmans, B.A.C.; Nicola, P.; Kvien, T.K.; McInnes, I.B.; Haentzschel, H.; GonzalezGay, M.A.; Provan, S.; et al. EULAR evidence-based recommendations for cardiovascular risk management in patients with rheumatoid arthritis and other forms of inflammatory arthritis. Ann. Rheum. Dis. 2009, 69, 325-331. [CrossRef]

112. Agca, R.; Heslinga, S.C.; Rollefstad, S.; Heslinga, M.; McInnes, I.B.; Peters, M.J.L.; Kvien, T.K.; Dougados, M.; Radner, H.; Atzeni, F.; et al. EULAR recommendations for cardiovascular disease risk management in patients with rheumatoid arthritis and other forms of inflammatory joint disorders: 2015/2016 update. Ann. Rheum. Dis. 2017, 76, 17-28. [CrossRef]

113. Komiyama, M.; Wada, H.; Ono, K.; Yamakage, H.; Satoh-Asahara, N.; Shimada, S.; Akao, M.; Morimoto, T.; Shimatsu, A.; Takahashi, Y.; et al. Smoking cessation reduces the lectin-like low-density lipoprotein receptor index, an independent cardiovascular risk marker of vascular inflammation. Heart Vessel. 2017, 33, 9-16. [CrossRef]

114. Benítez, S.; Sánchez-Quesada, J.L.; Lucero, L.; Arcelus, R.; Ribas, V.; Jorba, O.; Castellví, A.; Alonso, E.; Blanco-Vaca, F.; OrdóñezLlanos, J. Changes in low-density lipoprotein electronegativity and oxidizability after aerobic exercise are related to the increase in associated non-esterified fatty acids. Atherosclerosis 2002, 160, 223-232. [CrossRef]

115. Pocovi-Gerardino, G.; Correa-Rodríguez, M.; Callejas-Rubio, J.-L.; Ríos-Fernández, R.; Martín-Amada, M.; Cruz-Caparros, M.-G.; Rueda-Medina, B.; Ortego-Centeno, N. Beneficial effect of Mediterranean diet on disease activity and cardiovascular risk in systemic lupus erythematosus patients: A cross-sectional study. Rheumatology 2021, 60, 160-169. [CrossRef] [PubMed]

116. López-Longo, F.J.; Oliver-Miñarro, D.; De La Torre, I.; De Rábago, E.G.-D.; Sánchez-Ramón, S.; Rodríguez-Mahou, M.; Paravisini, A.; Monteagudo, I.; González, C.-M.; García-Castro, M.; et al. Association between anti-cyclic citrullinated peptide antibodies and ischemic heart disease in patients with rheumatoid arthritis. Arthritis Rheum. 2009, 61, 419-424. [CrossRef] [PubMed]

117. Winchester, R.; Giles, J.T.; Nativ, S.; Downer, K.; Zhang, H.-Z.; Bag-Ozbek, A.; Zartoshti, A.; Bokhari, S.; Bathon, J.M. Association of Elevations of Specific T Cell and Monocyte Subpopulations in Rheumatoid Arthritis With Subclinical Coronary Artery Atherosclerosis. Arthritis Rheumatol. 2015, 68, 92-102. [CrossRef]

118. Szabó, M.Z.; Szodoray, P.; Kiss, E. Dyslipidemia in systemic lupus erythematosus. Immunol. Res. 2017, 65, 543-550. [CrossRef]

119. Westlake, S.L.; Colebatch, A.N.; Baird, J.; Curzen, N.; Kiely, P.; Quinn, M.; Choy, E.; Ostor, A.J.K.; Edwards, C.J. Tumour necrosis factor antagonists and the risk of cardiovascular disease in patients with rheumatoid arthritis: A systematic literature review. Rheumatology 2010, 50, 518-531. [CrossRef] [PubMed]

120. Ait-Oufella, H.; Libby, P.; Tedgui, A. Anti-cytokine immune therapy and atherothrombotic cardiovascular risk. Arter. Thromb. Vasc. Biol. 2019, 39, 1510-1519. [CrossRef] [PubMed]

121. Ursini, F.; Ruscitti, P.; Caio, G.P.I.; Manfredini, R.; Giacomelli, R.; De Giorgio, R. The effect of non-YNF-targeted biologics on vascualr dysfunction in rheumatoid arthritis: A systemic literature review. Autoimmun. Rev. 2019, 18, 501-509. [CrossRef]

122. Wasko, M.C.; Dasgupta, A.; Sears, G.I.; Fries, J.F.; Ward, M.M. Prednisone Use and Risk of Mortality in Patients With Rheumatoid Arthritis: Moderation by Use of Disease-Modifying Antirheumatic Drugs. Arthritis Rheum. 2015, 68, 706-710. [CrossRef] [PubMed]

123. Danelich, I.M.; Wright, S.S.; Lose, J.M.; Tefft, B.J.; Cicci, J.D.; Reed, B.N. Safety of Nonsteroidal Antiinflammatory Drugs in Patients with Cardiovascular Disease. Pharmacother. J. Hum. Pharmacol. Drug Ther. 2015, 35, 520-535. [CrossRef]

124. Rempenault, C.; Combe, B.; Barnetche, T.; Gaujoux-Viala, C.; Lukas, C.; Morel, J.; Hua, C. Metabolic and cardiovascular benefits of hydroxychloroquine in patients with rheumatoid arthritis: A systematic review and meta-analysis. Ann. Rheum. Dis. 2018, 77, 98-103. [CrossRef]

125. Yang, D.-H.; Leong, P.-Y.; Sia, S.-K.; Wang, Y.-H.; Wei, J.C.-C. Long-Term Hydroxychloroquine Therapy and Risk of Coronary Artery Disease in Patients with Systemic Lupus Erythematosus. J. Clin. Med. 2019, 8, 796. [CrossRef]

126. Widdifield, J.; Abrahamowicz, M.; Paterson, J.M.; Huang, A.; Thorne, J.C.; Pope, J.E.; Kuriya, B.; Beauchamp, M.-E.; Bernatsky, S. Associations Between Methotrexate Use and the Risk of Cardiovascular Events in Patients with Elderly-onset Rheumatoid Arthritis. J. Rheumatol. 2018, 46, 467-474. [CrossRef] [PubMed]

127. Benítez, S.; Ordóñez-Llanos, J.; Franco, M.; Marín, C.; Paz, E.; López-Miranda, J.; Otal, C.; Pérez-Jiménez, F.; Sánchez-Quesada, J.L. Effect of simvastatin in familial hypercholesterolemia on the affinity of electronegative low-density lipoprotein subfractions to the low-density lipoprotein receptor. Am. J. Cardiol. 2004, 93, 414-420. [CrossRef] [PubMed] 
128. Zhang, B.; Matsunaga, A.; Rainwater, D.L.; Miura, S.-I.; Noda, K.; Nishikawa, H.; Uehara, Y.; Shirai, K.; Ogawa, M.; Saku, K. Effects of rosuvastatin on electronegative LDL as characterized by capillary isotachophoresis: The ROSARY Study. J. Lipid Res. 2009, 50, 1832-1841. [CrossRef] [PubMed]

129. Ding, Z.; Liu, S.; Wang, X.; Deng, X.; Fan, Y.; Shahanawaz, J.; Reis, R.J.S.; Varughese, K.I.; Sawamura, T.; Mehta, J.L. Cross-talk between LOX-1 and PCSK9 in vascular tissues. Cardiovasc. Res. 2015, 107, 556-567. [CrossRef]

130. Chu, C.-S.; Law, S.H.; Lenzen, D.; Tan, Y.-H.; Weng, S.-F.; Ito, E.; Wu, J.-C.; Chen, C.-H.; Chan, H.-C.; Ke, L.-Y. Clinical Significance of Electronegative Low-Density Lipoprotein Cholesterol in Atherothrombosis. Biomedicines 2020, 8, 254. [CrossRef]

131. Tian, K.; Ogura, S.; Little, P.J.; Xu, S.-W.; Sawamura, T. Targeting LOX-1 in atherosclerosis and vasculopathy: Current knowledge and future perspectives. Ann. N. Y. Acad. Sci. 2018, 1443, 34-53. [CrossRef] [PubMed]

132. Liu, M.; Tao, G.; Liu, Q.; Liu, K.; Yang, X. MicroRNA let-7g alleviates atherosclerosis via the targeting of LOX-1 in vitro and in vivo. Int. J. Mol. Med. 2017, 40,57-64. [CrossRef] [PubMed]

133. Dai, Y.; Wu, X.; Dai, D.; Li, J.; Mehta, J.L. MicroRNA-98 regulates foam cell formation and lipid accumulation through repression of LOX-1. Redox Biol. 2018, 16, 255-262. [CrossRef]

134. Fiordelisi, A.; Iaccarino, G.; Morisco, C.; Coscioni, E.; Sorriento, D. NFkappaB is a Key Player in the Crosstalk between Inflammation and Cardiovascular Diseases. Int. J. Mol. Sci. 2019, 20, 1599. [CrossRef] [PubMed]

135. Kauppinen, A.; Suueonen, T.; Ojala, J.; Kaarniranta, K.; Salminen, A. Antagonistic crosstalk between NF- $k B$ and SIRT1 in the regulation of inflammation and metabolic disorders. Cell. Signal. 2013, 25, 1939-1948. [CrossRef] [PubMed] 